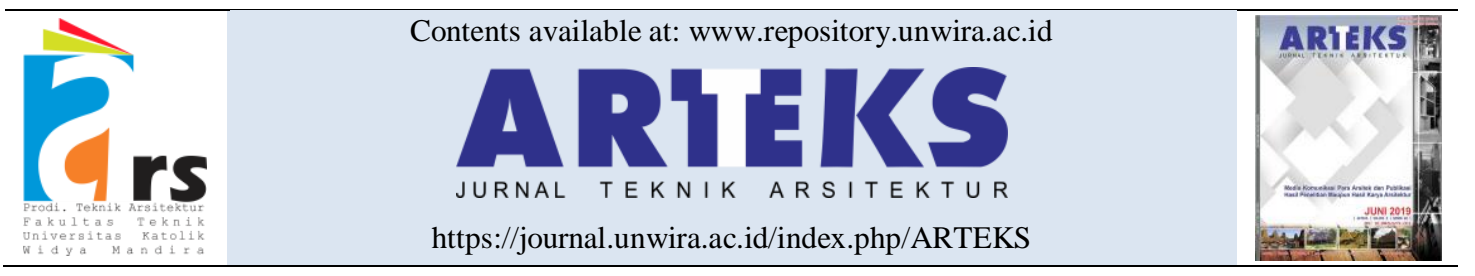

Editorial paper

doi: 10.30822/arteks.v5i2.531

\title{
Arsitektur sebagai realitas kemanusiaan \\ (Dari keseharian sampai kesadaran transendental)
}

\section{Sudaryono Sastrosasmito}

\author{
Advisory and Reviewer Board ARTEKS : Jurnal Teknik Arsitektur \\ Guru Besar dalam bidang Sejarah, Teori Perencanaa, dan Pengetahuan Lokal \\ dalam Arsitektur, Universitas Gadjah Mada, Indonesia \\ Email: sudaryono@ugm.ac.id
}

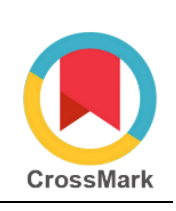

Edisi ARTEKS : Jurnal Teknik Arsitektur [Volume 5, issue 2, August 2020] kali ini menyajikan suatu anyaman pemikiran hasil riset, yang memotret arsitektur sebagai sosok realitas kehidupan manusia, mulai dari arsitektur sebagai ruang keseharian sampai pada arsitektur sebagai suatu kesadaran transendental. Secara ontologis, hasil riset yang tersaji dalam edisi ini dibangun di atas satuan-satuan ruang pedagang kaki lima (Setiyawan, et. al), hunian (Purnomo dan Fauzy; Prakoso dan Wilianto; Santoni, et. al; Yuliani, et. al; Darmayanti dan Bahauddin; Hidayat, et. al), wisata (Anisa dan Wati; Azyan, et. al; Ningsih, et. al.; Rahmah dan Aqli; Karima, et. al.), koridor kota (Ardhiansyah; Aprillia, et. al; Radliyatullah dan Dwisusanto), kawasan transit (Setiawan dan Ikaputra), dan Masjid (Paramitha dan Salura; Huldiansyah dan Subroto). Sedangkan secara epistemologis, payung berpikir yang digunakan dalam penelitian yang tersaji mencakup pendekatan-pendekatan: (1) perilaku ruang (Santoni, et. al; Setiyawan, et. al; Radliyatullah dan Dwisusanto), (2), arsitektur organik (Anisa dan Wati; Azyan, et. al.), (3) transit-oriented development (Setiawan dan Ikaputra), (4) arsitektur hijau (Yuliani, et. al; Aprillia, et. al.), (5) arsitektur vernakular (Prakoso dan Wilianto; Hidayat, et. al), (6) arsitektur vandalism (Ardhiansyah), (7) akulturasi arsitektur (Purnomo dan Fauzy), (8) geometri dan konfigurasi ruang (Huldiansyah dan Subroto; Darmayanti dan Bahauddin; Azyan, et. al; Ningsih, et. al.; Rahmah dan Aqli; Karima, et. al.), dan (9) ruang sakral (sacred space) (Paramitha dan Salura).

Sebagai ruang keseharian, kalau mengacu pada Lefebvre (1992), maka arsitektur merupakan realitas kekinian dari pengalaman ruang (perceived space), atau merupakan praktek keruangan kekinian (spatial practice) (Lefebvre 1992), seperti ruang pedagang kaki lima, hunian, kawasan wisata, koridor kota, dan kawasan transit. Sebagai ruang keseharian, arsitektur melibatkan jaringan kegiatan (sosial, budaya, ekonomi), jaringan fisik-spasial (peta pergerakan), dan jaringan waktu (keterulangan peristiwa ruang). Vandalisme ruang, misalnya, yang terpotret dari salah satu koridor Kota Yogyakarta, merupakan ruang yang memiliki makna dan memberi pengalaman penting bagi keseharian para pelaku vandalisme. Vandalisme, merupakan akumulasi dari pengalaman ruang (urban reality), jaringan kekotaan (urban networks) dan perilaku keseharian dari pelaku vandalisme.

Sebagai ruang keseharian, maka arsitektur bukanlah ruang kosong yang kering dan dingin, karena di dalamnya ada proses mental yang terbangun oleh para pelaku atau pemiliki arsitektur. Arsitektur adalah titik bangkit sekaligus titik temu dari peristiwa relasi sosial, ekonomi, dan budaya dari para pemilik dan pelaku arsitektur. Dengan demikan, arsitektur dalam pemahaman para penulis Edisi ARTEKS : Jurnal Teknik Arsitektur kali ini, bukan hanya sekadar gambar (picture) atau rancangan (design), melainkan arsitektur sebagai realitas (reality) dan sebagai pengalaman (perceived architecture). Hal ini sejalan dengan pemahaman Sastrosasmito (2019), tentang "arsitektur yang diperluas" sebagai ontologi baru dalam konteks Revolusi Industri 4.0 (Sastrosasmito 2019).

Tentang realitas yang kedua, yakni arsitektur sebagai kesadaran transendental, yang dalam Edisi ARTEKS : Jurnal Teknik Arsitektur kali ini diwakili oleh artikel yang membahas masjid, maka arsitektur 
telah dipahami sebagai anyaman dari lapisan-lapisan kesadaran seperti yang digambarkan oleh Husserl $(2019,1965,1970)$ dan Heidegger (2008); arsitektur merupakan keutuhan anyaman dari lapis sensualfisik-spasial (life world), lapis kesadaran tujuan-konsepsional (intensionality), dan lapis kesadaran transendental (transcendental consiousness) (Heidegger 2008; Husserl 2019; 1965; 1970). Sakralitas ruang dan konsistensi ruang, yang merupakan temuan penting dalam artikel yang tersaji kali ini, merupakan cermin dari kesadaran transendental yang bersemayam baik di dalam arsitektur Masjid itu sendiri (dalam bentuk jenis dan fungsi ruang, konfigurasi ruang, dan simbo-simbol ruang), maupun yang bersemayam dalam alam pikiran pemilik dan pelaku ruang arsitektur Masjid.

Konsistensi ruang, merupakan hasil dari keterulangan yang teruji oleh waktu yang panjang. Keterulangan ruang merupakan hasil dari konsensus ruang, dan konsensus ruang terjadi karena adanya rujukan nilai yang sama, sedangkan rujukan ruang bersemayam dalam alam kesadaran ideal pelaku ruang, yang oleh Husserl kesadaran ideal ini disebutnya sebagai kesadaran transendental. Demikian juga dengan sakralitas ruang, yang secara empiri sensual tercermin pada penghormatan pelaku dan pemilik ruang atas ruang-ruang tertentu. Sedangkan sebagai kesadaran transendental, sakralitas hidup bersemayam dalam alam pikiran pemilik dan pelaku ruang dalam bentuk nilai-nilai yang menjadi sandaran keyakinan dan kepercayaan para pelaku dan pemilik ruang untuk "mengisi" dan "menghidupkan" ruang melalui perilaku meruang.

Pesan dari artikel-artikel yang tersaji pada Edisi ARTEKS : Jurnal Teknik Arsitektur kali ini adalah, bahwa arsitektur bukanlah sekadar peristiwa rancang bangun; arsitektur bukanlah sekadar komposisi dan konfigurasi; arsitektur bukanlah sekadar kemasan pikiran-pikiran besar dunia (narasi besar) yang menempel pada sosok yang diciptakan dengan kebanggaan semu yang tidak sadar; arsitektur bukanlah sekadar artikulasi dari citra pribadi yang dilebih-lebihkan; arsitektur adalah "manusia dan kemanusiaan"; arsitektur adalah "jiwa yang menubuh" (Sastrosasmito 2019).

\section{Referensi}

Heidegger, Martin. 2008. Towards the Definition of Philosophy: The Idea of Philosophy and the Problem of World View, Phenomenology and Transcendental Philosophy of Value. Continuum Impacts. Reprint. London: A\&C Black.

Husserl, Edmund. 1965. Phenomenology and the Crisis of Philosophy. Edited by Quentin Lauer. Harper Torchbooks The Academy Library TB 1170. 1st ed. New York: Harpercollins.

- 1970. The Crisis of European Sciences and Transcendental Phenomenology: An Introduction to Phenomenological Philosophy. Edited by David Carr. Evanston: Northwestern University Press.

—. 2019. The Phenomenology of Internal Time-Consciousness. Edited by Martin Heidegger. Translated. Indiana University Press. https://doi.org/10.2307/j.ctvh4zhv9.

Lefebvre, Henri. 1992. The Production of Space. Edited by Donald Nicholson Smith. The Production of Space. 1 edition. United States: Wiley-Blackwell.

Sastrosasmito, Sudaryono. 2019. “Tubuh-Jiwa-Roh Arsitektur Dalam Pusaran RI-4.0". In DDskusi Meja Bundar: The End of Architecture: Long Live Architecture? Bandung: Kelompok Keahlian Sejarah, Teori, dan Kritik Arsitektur, Sekolah Arsitektur, Perencanaan, dan Pengembangan Kebijakan, Institut Teknologi Bandung. 